\title{
Peran Kelembagaan Dalam Mendorong Orientasi Kewirausahaan Untuk Meningkatkan Kinerja Usaha Peternakan Ayam Petelur Di Kecamatan Baranti Kabupaten Sidrap
}

\author{
the role of institutions in encouraging entrepreneurial orientation \\ to improve the business performance of laying hens \\ in baranti district, sidrap regency \\ Mariam $^{1}$, Andi Rusdi Walinono', Sumarni ${ }^{1}$ \\ 1)Jurusan Agribisnis Perikanan Politeknik Pertanian Negeri Pangkajene Kepulauan \\ *Corresponding author: maryamarief@gmail.com
}

Diterima tanggal 03 Maret 2020, Disetujui tanggal 29 Maret 2020

\begin{abstract}
Abstrak
Tujuan penelitan ini adalah untuk mengukur dan manganalisis pengaruh orientasi kewirausahaan terhadap kinerja usaha peternakan ayam ras petelur, pengaruh peran kelembagaan dalam memperkuat kinerja usaha peternakan ayam ras petelur. Penelitian ini dilakukan pada usaha peternakan ayam ras petelur di Kecamatan Baranti Kabupaten Sidrap. Metode penelitian yang digunakan pada penelitian ini adalah observasi lapangan dan wawancara dengan pihak terkait usaha peternakan ayam ras petelur. Data hasil penelitian dianalisis menggunakan struktural equation modeling (SEM) dengan pendekatan varians atau biasa disebut Partial least square path modeling (PLS-PM). Analisis data dilakukan menggunakan program aplikasi statistic XLSTAT. Hasil penelitian menunjukkan bahwa orientasi kewirausahaan berpengaruh nyata secara positif terhadap kinerja usaha. Sedangkan peran kelembagaan tidak berpengaruh nyata terhadap memperkuat pengaruh orientasi kewirausahaan terhadap kinerja usaha. Orientasi kewirausahaan mampu meningkatkan kinerja usaha ayam petelur, namun faktor kelembagaan belum befungsi dengan baik dalam mengembangkan usaha peternakan ayam ras petelur.
\end{abstract}

Kata kunci : Orientasi kewirausahaan, peran kelembagaan, kinerja usaha

\begin{abstract}
The purpose of this research are: To measure and analyze how much influence the entrepreneurial orientation has on the performance of laying hens. end measure and analyze how much influence the role of institutions in strengthening the effect of entrepreneurial orientation on the performance of laying hens. The research method used in this study is to conduct observations, interviews by distributing questionnaires to respondents in laying chicken farms. The analytical method used in this research is Structural Equation Modeling (SEM) with variance approach or commonly called Partial least square path modeling (PLS-PM) .. The analytical tool used is the XLSTAT statistical application program. This research was conducted at the laying chicken farms in the District of Baranty, Sidrap Regency. The results showed that entrepreneurial orientation had a significant positive effect on business performance. The role of institutions does not significantly strengthen theeffect of entrepreneurial orientation on business performance.Entrepreneurial orientation is able to improve the performance of laying hens, but institutional factors have not functioned well in developing the business of laying hens.
\end{abstract}

Keywords: Entrepreneurial orientation, institutional role, business performance 


\section{PENDAHULUAN}

Pembangunan sub sektor peternakan yang berwawasan agribisnis merupakan upaya sistematis dalam memainkan peranan yang aktif dan positif di dalam pembangunan nasional untuk meningkatkan pertumbuhan ekonomi, pemerataan dan stabilitasi nasional. Salah satu peran penting dari sub sektor peternakan dalam pembangunan adalah dalam rangka mendorong pertumbuhan dan dinamika ekonomi pedesaan. Terdapat 3 (tiga) pendekatan yang akan mewarnai pembangunan sub sektor peternakan yaitu pendekatan agribisnis, pendekatan keterpaduan dan pendekatan sumberdaya wilayah. Perkembangan usaha peternakan ayam ras petelur di Indonesia pada umumnya berkembang sangat pesat sehingga untuk memenuhi kebutuhan konsumsi daging ayam dalam negeri tidak perlu melakukan impor daging ayam dari luar. Kondisi ini menjadi motivasi bagi para peternak untuk mempertahankan prestasi yang diraih serta berusaha mengembangkan usahanya. Usaha peternakan ayam ras petelur memiliki keunggulan dari segi pendapatan karena selain dapat diperoleh dari hasil penjualan daging, dapat juga dari penjualan telur (Pradasari, 2013 dalam Anwar et.al, 2016).

Konsumsi telur ayam ras oleh masyarakat Indonesia diperkirakan akan terus mengalami peningkatan. $\mathrm{Hal}$ ini diakibatkan oleh harga telur ayam ras yang sangat kompetitif dan lebih murah dibandingkan jenis telur lainnya. Telur ayam juga merupakan sumber protein bermutu tinggi, kaya akan vitamin dan mineral. Adanya selera dan kebiasaan konsumen yang lebih menyukai telur ayam ras untuk dikonsumsi juga diindikasikan sebagai penyebab meningkatnya penjualan telur ayam ras. (Sirajuddin dkk, 2016). Usaha peternakan ayam ras petelur di Sulawesi Selatan saat ini pada umumnya berkembang pesat di berbagai daerah seperti di Kabupaten Sidrap, Bantaeng, Wajo, Pinrang dan beberapa daerah lainnya (Dinas Peternakan Sulsel, 2012). Aktivitas peternakan dibeberapa daerah sejak dulu telah dilakukan dan mampu bertahan serta berkembang sampai saat ini, demikian halnya untuk daerah Kabupaten Sidrap, usaha peternakan ayam ras petelur terus mengalami perkembangan yang dapat dilihat dari peningkatan jumlah populasi ternak dan peternak ayam ras petelur (Badan Pusat Statistik Kabupaten Sidrap, 2015).

Woolfolk, (2004 dalam Rahmah, 2018) menjelaskan bahwa sebagai seorang wirausaha pada usaha yang memiliki risiko tinggi seperti peternakan ayam ras petelur maka para peternak harus mampu mengelola usahanya dengan baik. Karakteristik individu wirausaha merupakan salah satu hal yang melekat pada diri seorang wirausaha. Karakteristik individu merupakan ciri-ciri yang dimiliki oleh individu sepanjang hidupnya, meliputi faktor kognitif dan karakteristik lain yang dimiliki individu yang menentukan dalam proses belajar. Rohani dan susanti (2012) dalam studinya mengatakan bahwa pengalaman beternak akan mampu meningkatkan skala usaha para peternak ayam petelur. Rahmah (2018) telah melaporkan terdapat hubungan yang positif dan signifikan antara karakteristik kewirausahaan dengan kinerja usaha peternak ayam ras petelur. Peningkatan keseluruhan kinerja usaha dapat dilakukan dengan meningkatkan karakteristik percaya diri dan inovatif, demikian halnya dengan diskusi, berbagi informasi dan pengalaman perlu dilakukan dalam rangka meningkatkan kinerja usaha. Dijelaskan juga bahwa pemerintah ikut berperan dalam meningkatkan karakteristik kewirausahaan dan kinerja usaha dengan cara mengadakan pelatihan yang berkaitan dengan kepemimpinan dan kerja keras agar kinerja usaha menjadi meningkat.

Haliq (2017), telah melakukan penelitian pada usaha peternakan ayam broiler di Bogor, dan menemukan bahwa pada pola kemitraan, ditemukan pengaruh negatif dan tidak signifikan 
orientasi kewirausahaan terhadap kinerja usaha. Sementara pada pola mandiri orientasi kewirausahaan berpengaruh positif dan signifikan terhadap kinerja usaha. Hal ini menunjukkan bahwa orientasi kewirausahaan berperan penting dalam peningkatan kinerja usaha ternak ayam broiler pada pola mandiri di Kabupaten Bogor. Disamping itu dukungan pemerintah dalam hal kebijakan atau aturan-aturan seperti kemudahan dalam peminjaman modal usaha ternak serta memfasilitasi peternak sebagai penyedia bibit, pakan ternak, obat hingga sarana peternakan.

Artikel ini akan membahas tentang peran kelembagaan dalam mendorong orientasi kewirausahaan untuk meningkatkan kinerja usaha peternakan ayam petelur di Kecamatan Baranti Kabupaten Sidrap.

\section{BAHAN DAN METODE}

Waktu dan Tempat Penelitian

Penelitian ini dilaksanakan pada

tahun 2019 di Kecamatan Baranti

Kabupaten Sidrapselama 8 bulan. Di

mulai pada bulan April 2019 hingga

bulan November 2019

\section{Populasi dan Sampel Penelitian}

adalah Populasi dalam penelitian ini usahapeternakan ayam ras petelur di Kecamatan Baranti Kabupaten Sidrap. Sampel dalam penelitian ini ditentukan 50 sampel sesuai dengan syarat alat analisis Partial Least Square (Path Modeling) yaitu minimal $30-100$ sampel. Teknik pengambilan sampel dalam penelitian ini adalah: 1) purposive sampling (secara sengaja) yaitu responden yang termasuk dalam kelompokusaha peternakan ayam petelur.

\section{Teknik Pengambilan Data}

1. Observasi

Observasi dilakukan dengan cara melakukan pengamatan langsung ke lokasi penelitian dengan melihat usaha peternakan ayam ras petelur di kecamatan baranti kabupaten Sidrap.

2. Kuesioner

Kuesioner disusun dalam bentuk pertanyaan pertanyaan tertulis yang diberikan kepada responden. Menurut Sugiyono (2006) kuisioner merupakan teknik pengumpulan data yang efisien bila peneliti tahu dengan pasti variabel yang akan diukur dan tahu apa yang bisa diharapkan dari responden.

\section{Analisa Data}

Metode analisis yang digunakan dalam penelitian ini adalah Struktural equation modeling (SEM) dengan pendekatan varians atau biasa disebut Partial least square path modeling (PLSPM). Pendekatan SEM berbasis varians digunakan sebagai alternative bila asumsi dasar peneliti ketika akan menggunakan model adalah tujuan prediksi (Sofyan Yamin, 2011). Alat analisis yang digunakan adalah program aplikasi statistic XLSTAT 2014.

\section{HASIL DAN PEMBAHASAN \\ HASIL}

\section{Deskripsi responden berdasarkan} umur dan skala usaha

Deskripsi responden berdasarkan umur dan skala usaha menggambarkan tentang jumlah responden berdasarkan umur/usia dan skala usaha yang dimiliki. Deskripsi responden seperti pada Tabel 1 dibawah:

Tabel 1. Deskripsi umur dan skala usaha responden

\begin{tabular}{lcccc}
\hline Usia (Tahun) & \multicolumn{4}{c}{ Skala Usaha } \\
& $<2000$ & $2000-4000$ & $>4000$ & jumlah \\
\hline $10-20$ & - & - & - & - \\
$21-30$ & 7 & 3 & 2 & $12(24 \%)$ \\
$31-40$ & 9 & 6 & 2 & $17(34 \%)$ \\
$41-50$ & 3 & 4 & 4 & $11(22 \%)$ \\
$>50$ & 2 & 5 & 5 & $10(20 \%)$ \\
\hline & 21 & 18 & 11 & $50(100 \%)$ \\
\hline
\end{tabular}

Sumber : Data primer diolah 2019

Karakteristik berdasarkan umur dan skala usaha menunjukkan bahwa responden dengan 21-30 tahun 
sebanyak 12 orang. Rseponden dengan umur 31-40 tahun sebanyak 17 orang. Responden dengan umur 41-50 tahun sebanyak 11 orang. Dan responden dengan umur diatas 50 tahun sebanyak 10 orang. Adapun jumlah responden dengan skala usaha di bawah 2000 ekor sebanyak 21 orang. Responden yang memiliki skala usaha 2000 hingga 4000 ekor sebanyak 18 orang. Dan responden yang memiliki skala usaha diatas 4000 ekor sebanyak 11 orang.

\section{Tingkat pendidikan responden}

Tingkat pendidikan responden merupakan jenjang pendidikan formal yang pernah dilalui oleh responden. Tingkat pendidikan responden seperti pada Tabel 2 di bawah ini:

Tabel 2.Tingkat pendidikan responden

\begin{tabular}{lc}
\hline Tingkat pendidikan & Jumlah \\
\hline SD & 9 \\
SMP & 11 \\
SMA & 27 \\
Perguruan Tinggi & 3 \\
\hline T O T A L & 50
\end{tabular}

Sumber: Data primer diolah 2019

Tingkat pendidikan responden menggambarkan bahwa responden dengan tingkat pendidikan SD sebanyak 9 orang, responden dengan tingkat pendidikan SMP sebanyak 11 orang, yang berjenjang SMA sebanyak 27 orang, dan tingkat perguruan tinggi sebanyak 3 orang.

\section{Pengalaman beternak responden} Pengalaman

beternak merupakan pengetahuan yang diperoleh oleh responden dalam beternak berdasarkan lamanya mereka beternak. Pengalaman beternak responden dapat dilihat pada Tabel 3 dibawah:

Tabel 3.Pengalaman beternak

\begin{tabular}{lc}
\hline $\begin{array}{l}\text { Pengalaman } \\
\text { beternak (Tahun) }\end{array}$ & Jumlah \\
\hline$<5$ & 19 \\
$6-10$ & 16 \\
$11-15$ & 9 \\
$16-20$ & 4 \\
$>20$ & 2 \\
\hline T O T A L & 50 \\
\hline \multicolumn{2}{c}{ Sumber: Data primer diolah 2019}
\end{tabular}

Responden yang memiliki pengalaman kurang dari lima tahun sebanyak 19 orang, yang memiliki pengalaman 6-10 tahun sebanyak 16 orang, pengalaman 11-15 tahun sebanyak 9 orang, yang berpengalaman 16-20 tahun sebanyak 4 orang, dan diatas 20 tahun sebanyak 2 orang.

Deskripsi jawaban responden

Deskripsi jawaban responden merupakan alternatif pilihan jawaban yang diberikan oleh responden pada kuesioner yang menjadi pilihan skor pada setiap indikator masing-masing variabel. Jawaban responden dapat dilihat pada tabel 4 di bawah:

Tabel 4. Deskripsi jawaban responden

\begin{tabular}{|c|c|c|c|c|c|}
\hline Variable & $\begin{array}{c}\text { Obser } \\
\text { vations }\end{array}$ & Minimum & Maximum & Mean & $\begin{array}{c}\text { Std. } \\
\text { deviation }\end{array}$ \\
\hline$X 1$ & 50 & 3,0000 & 6,0000 & 5,2000 & 0,7211 \\
\hline $\mathrm{x} 2$ & 50 & 3,0000 & 6,0000 & 5,3200 & 0,8109 \\
\hline$x 3$ & 50 & 3,0000 & 6,0000 & 5,2400 & 0,7088 \\
\hline M1 & 50 & 4,0000 & 6,0000 & 5,1200 & 0,6823 \\
\hline M2 & 50 & 4,0000 & 6,0000 & 5,2200 & 0,7291 \\
\hline M3 & 50 & 4,0000 & 6,0000 & 5,2800 & 0,6940 \\
\hline Y1 & 50 & 3,0000 & 6,0000 & 5,2000 & 0,7211 \\
\hline Y2 & 50 & 3,0000 & 6,0000 & 5,2000 & 0,8718 \\
\hline Y3 & 50 & 3,0000 & 6,0000 & 5,1000 & 0,7280 \\
\hline $\mathrm{X} 1{ }^{*} \mathrm{M} 1$ & 50 & $-1,8210$ & 2,7314 & 0,3983 & 0,9911 \\
\hline $\mathrm{X} 1{ }^{*} \mathrm{M} 2$ & 50 & $-1,7803$ & 2,7845 & 0,4489 & 0,9312 \\
\hline $\mathrm{X} 1{ }^{*} \mathrm{M} 3$ & 50 & $-1,7265$ & 3,0693 & 0,4076 & 0,9303 \\
\hline $\mathrm{X} 2{ }^{*} \mathrm{M} 1$ & 50 & $-1,3764$ & 4,6959 & 0,5451 & 0,9861 \\
\hline $\mathrm{X} 2{ }^{*} \mathrm{M} 2$ & 50 & $-1,7414$ & 4,7871 & 0,4898 & 1,0432 \\
\hline $\mathrm{X} 2 * \mathrm{M} 3$ & 50 & $-0,4094$ & 5,2768 & 0,5871 & 1,0552 \\
\hline $\mathrm{X} 3^{*} \mathrm{M} 1$ & 50 & $-0,4367$ & 2,8715 & 0,3953 & 0,6932 \\
\hline $\mathrm{X} 3^{\star} \mathrm{M} 2$ & 50 & $-1,8715$ & 2,9273 & 0,4396 & 0,8165 \\
\hline $\mathrm{X} 3^{*} \mathrm{M} 3$ & 50 & $-1,8150$ & 3,2267 & 0,3513 & 0,8826 \\
\hline
\end{tabular}

Sumber: Data diolah 2010

Dari tabel 4 diatas terlihat bahwæ9

indikator variabel orientasi kewirausahaan, memiliki nilai rata-rata (mean) maximum pada indikator $\mathrm{X} 2$ yaitu sebesar 5,3200 dan nilai rata-rata minimum pada indikator X1 sebesar 5,2000 . Untuk variabel kelembagaan, nilai rata-rata maximum pada indikator 
M3 sebesar 5,2800 dan nilai rata-rata minimum pada indikator M1 sebesar 5,1200 . Sedangkan pada variabel kinerja usaha, nilai rata-rata maximum pada indikator Y1 dan Y2 sebesar 5,2000 dan minimum pada indikator Y3 sebesar 5,1000 .

\section{Analisis pengukuran}

Analisis pengukuran dilakukan
terlebih dahulu sebelum langkah pengujian hipotesis untuk mengukur validitas dan reliabilitas indikator setiap variabel. Setelah dilakukan analisis pengukuran pada indikator variabel, ada beberapa indikator yang dibuang karena tidak valid setelah dilakukan pengukuran. Hasil evaluasi pengukuran selanjutnya setelah beberapa indikator pada masingmasing variabel dibuang adalah seperti pada tabel 5 dibawah:

Tabel 5. Korelasi indikator

\begin{tabular}{|c|c|c|c|c|c|}
\hline Orienta & $\begin{array}{l}\text { Si Kewira } \\
\text { usahaan }\end{array}$ & $\begin{array}{l}\text { Kelem } \\
\text { bagaan }\end{array}$ & $\begin{array}{l}\text { Kinerja } \\
\text { Usaha }\end{array}$ & $\overline{X^{*} M}$ & $\begin{array}{l}\text { Anatisis uji hipotesis } \\
\text { Berdasarkan analisis pengukuran }\end{array}$ \\
\hline $\begin{array}{l}\mathrm{X} 10 \\
\times 20 \\
\times 30\end{array}$ & $\begin{array}{l}82260 \\
89030 \\
83960\end{array}$ & $\begin{array}{l}46830 \\
59920 \\
44280\end{array}$ & $\begin{array}{l}5514 \\
6621 \\
5965\end{array}$ & $\begin{array}{l}-0,2914 \\
-0,4571 \\
-0,1937\end{array}$ & $\begin{array}{l}\text { yang dilakukan, semua model memenuhi } \\
\text { persyaratan/dapat dikonfirmasi untuk }\end{array}$ \\
\hline $\begin{array}{l}\text { M1 } \\
\text { M20, } \\
\text { M30, }\end{array}$ & $\begin{array}{l}0,53710 \\
54130 \\
54600\end{array}$ & $\begin{array}{l}84530 \\
92850 \\
90930\end{array}$ & $\begin{array}{l}5956 \\
6760 \\
6499\end{array}$ & $\begin{array}{l}-0,2263 \\
-0,3269 \\
-0,3563\end{array}$ & 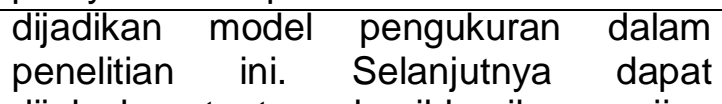 \\
\hline $\begin{array}{l}\text { Y10, } \\
\text { Y20, } \\
\text { Y30, }\end{array}$ & $\begin{array}{l}39100 \\
68580 \\
66530\end{array}$ & $\begin{array}{l}51370 \\
71670 \\
53720\end{array}$ & $\begin{array}{l}6798 \\
9400 \\
8798 \\
\end{array}$ & $\begin{array}{l}-0,0665 \\
-0,4045 \\
-0,2423\end{array}$ & $\begin{array}{l}\text { dijelaskan tentang hasil-hasil pengujian } \\
\text { hipotesis. Hasil estimasi model tersebut }\end{array}$ \\
\hline $\mathrm{X} 1{ }^{*} \mathrm{M} 1$ & $-0,2477$ & $-0,1749$ & $-0,1780$ & 0,6828 & thut \\
\hline $\mathrm{X} 1{ }^{*} \mathrm{M} 2$ & $-0,2464$ & $-0,3103$ & $-0,3019$ & 0,8072 & \\
\hline $\mathrm{X} 1{ }^{*} \mathrm{M} 3$ & $-0,3127$ & $-0,2948$ & $-0,3012$ & 0,8552 & \\
\hline $\mathrm{X} 2^{*} \mathrm{M} 1$ & $-0,3385$ & $-0,2516$ & $-0,1433$ & 0,7545 & \\
\hline $\begin{array}{l}\mathrm{X} 2^{*} \mathrm{M} 2 \\
\mathrm{X} 2^{*} \mathrm{M} 3\end{array}$ & $\begin{array}{l}-0,3394 \\
-0,4534\end{array}$ & $\begin{array}{l}-0,3012 \\
-0,3563\end{array}$ & $\begin{array}{l}-0,2765 \\
-0,3434\end{array}$ & $\begin{array}{l}0,9011 \\
0,9153\end{array}$ & \\
\hline $\mathrm{X}^{*} \mathrm{M} 1$ & $-0,0888$ & $-0,02230$ & 0412 & 0,5063 & \\
\hline $\mathrm{X} 3^{\star} \mathrm{M} 2$ & $-0,1441$ & $-0,1391$ & $-0,1871$ & 0,6639 & \\
\hline $\mathrm{X} 3^{\star} \mathrm{M} 3$ & $-0,2701-0,2$ & $2220-0,27$ & 170,7143 & & \\
\hline
\end{tabular}

X3*M3 -0,2701-0,2220-0,27170,7143

$\begin{array}{llr}\text { Dari tabel } & 5 \text { diatas } & \text { semua } \\ \text { indikator dari } & \text { variabel } & \text { orientasi } \\ \text { kewirausahaan } & \text { memiliki } & \text { nilai }\end{array}$ standardized loading lebih besar dari 0,5, sehingga dapat dikatakan valid. Untuk variabel kelembagaan memiliki nilai standardized loading lebih besar dari 0,5 sehingga dapat dikatakan valid. Demikian juga untuk indikator variabel kinerja memiliki nilai standardized loading lebih besar dari 0,5 sehingga dapat dikatakan valid.
Evaluasi pengukuran selanjutnya adalah pengujian reliabilitas indikator dari setiap variabel. Evaluasi pengukuran untuk reliabilitas indikator variabel dapat dilihat pada nilai crombach's alpha dan DG rho seperti pada Tabel 6 dibawah:

Tabel 6. Composite reliability

\begin{tabular}{lccc}
\hline Laten Variabel & Dimensi & Cronbach's alpha & D.G.rho(PCA) \\
\hline $\begin{array}{l}\text { Orientasi } \\
\text { Kewirausahaan }\end{array}$ & 3 & 0,8119 & 0,8899 \\
\hline Kelembagaan & 3 & 0,8761 & 0,9342 \\
\hline $\mathrm{X}^{*} \mathrm{M}$ & 9 & 0,9150 & 0,9342 \\
\hline Kinerja Usaha & 3 & 0,8021 & 0,8888 \\
\hline
\end{tabular}

Sumber:Data diolah penulis, 2019

Dari tabel diatas terlihat bahwa nilai crombach's alpha dan nilai D'G rho untuk semua variabel lebih besar dari 0,7 sehingga dapat dikatakan bahwa semua indikator pada masing-masing variabel adalah reliabel atau dapat diandalkan.

\section{Analisis uji hipotesis}

yang dilakukan, semua model memenuhi persyaratan/dapat dikonfirmasi untuk dijadikan model pengukuran dalam penelitian ini. Selanjutnya dapat dijelaskan tentang hasil-hasil pengujian hipotesis. Hasil estimasi model tersebut dapat dilihat pada gambar berikut ini: 


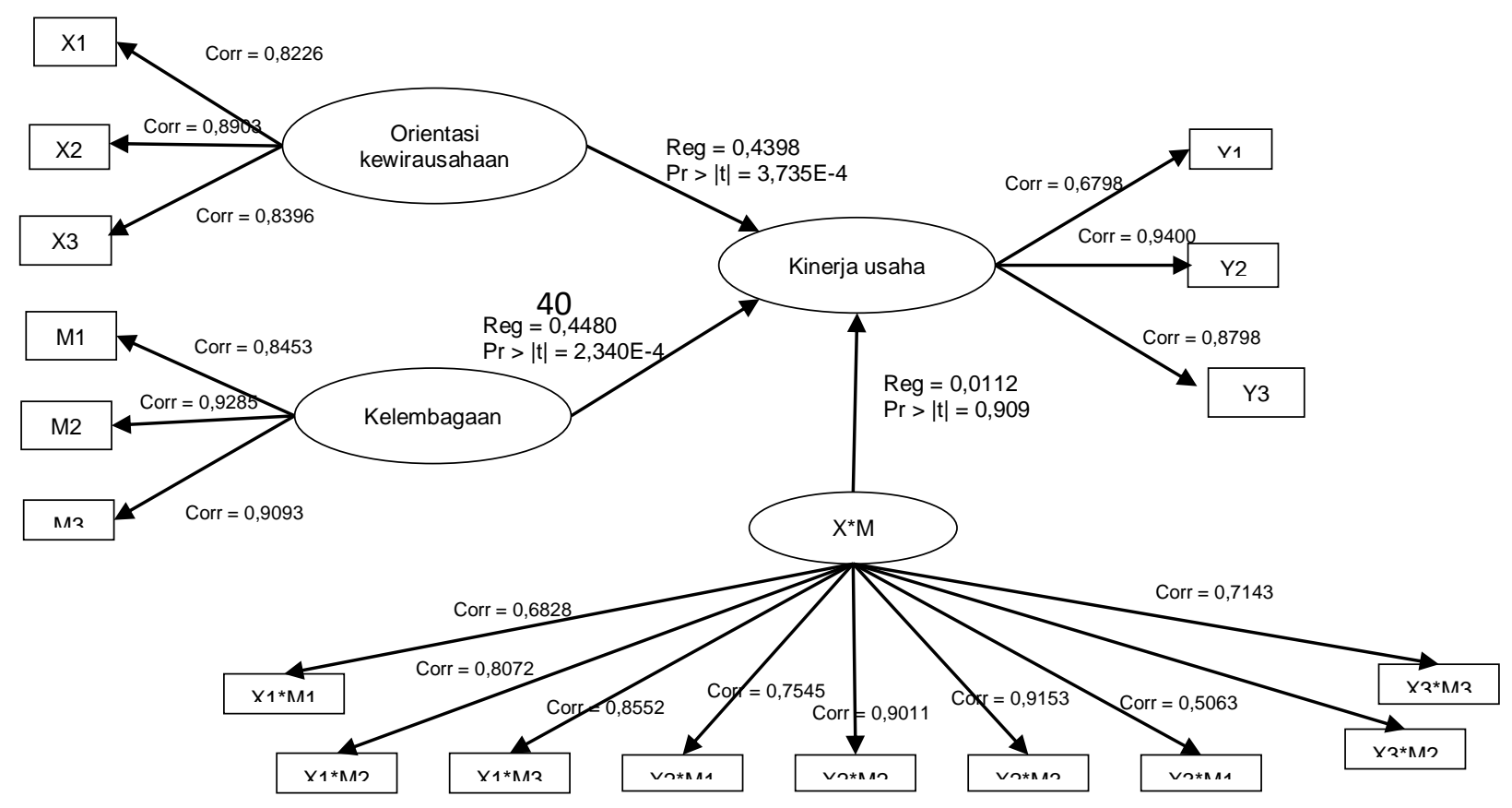

Gambar 1.Hasil pengujian hipotesis 
Analisis model structural dapat dilihat pada table 7dibawah ini:

Tabel 7. Koefisien jalur

Path coefficients (Kinerja usaha / 1):

\begin{tabular}{|c|c|c|c|c|c|}
\hline $\begin{array}{c}\text { Latent } \\
\text { variable }\end{array}$ & Value & $\begin{array}{c}\text { Standard } \\
\text { error }\end{array}$ & $\mathrm{t}$ & $\operatorname{Pr}>|t|$ & $\begin{array}{c}\text { Critical } \\
\text { ratio } \\
(\mathrm{CR}) \\
\end{array}$ \\
\hline $\begin{array}{l}\text { Intercept } \\
\text { Orientasi } \\
\text { kewira }\end{array}$ & 0,0000 & 0,0877 & 0,0000 & 1,0000 & 0,6295 \\
\hline $\begin{array}{l}\text { usahaan } \\
\text { Kelem }\end{array}$ & 0,4398 & 0,1145 & 3,8409 & 0,0004 & 3,1085 \\
\hline bagaan & 0,4480 & 0,1122 & 3,9915 & 0,0002 & 3,1321 \\
\hline$X^{*} M$ & 0,0112 & 0,0972 & 0,1152 & 0,9088 & 0,0831 \\
\hline
\end{tabular}

$R^{2}$ (Kinerja usaha / 1):

\begin{tabular}{ccc}
\hline$R^{2}$ & $F$ & $P r>F$ \\
\hline 0,6392 & 27,1665 & 0,0000 \\
\hline
\end{tabular}

Sumber: data di olah penulis 2018

Dari tabel diperoleh bahwa Orientasi kewirausahaan berpengaruh signifikan terhadap kinerja usaha.Konstrak kelembagaan tidak signifikan memperkuat pengaruh orientasi kewirausahaan terhadap kinerja usaha.Konstrak orientasi kewirausahaan, konstrak kelembagaanserta interaksinya berpengaruh terhadap kinerja usaha. Konstrak orientasi kewirausahaan dan konstrak kelembagaan serta interaksinya mampu menjelaskan variability konstrak kinerja usaha, sedangkan sisanya dijelaskan oleh faktor-faktor lainnya.

\section{PEMBAHASAN}

Dari hasil penelitian ini diperoleh bahwa orientasi kewirausahaan berpengaruh signifikan terhadap kinerja usaha, artinya bahwa kinerja usaha ayam petelur ditentukan oleh orientasi kewirausahaan. Pengusaha ayam petelur secara aktif mengeksplorasi peluang bisnis yang luas, demikian juga berbagi visi terhadap risiko pasar yang ada, serta sangat menerima cara inovatif untuk mengeksploitasi peluang pasar yang ada. Melalui upaya-upaya seperti itu, para pengusaha ayam petelur mampu meningkatkan kinerja usahanya. Penelitian ini sejalan dengan penelitian yang dilakukan oleh Kumalaningrum (2012) yang menyatakan bahwa perusahaan dengan orientasi kewirausahaan dapat mencapai target pasar dan posisi pasar lebih dibandingkan para pesaing mereka. Perusahaan selalu mengamati perubahan pasar dan melakukan respon dengan dengan cepat terhadap perubahan tersebut. Hasil penelitian ini juga sejalan dengan yang dilakukan oleh Febriatmoko dan Raharjo (2015) bahwa orientasi wirausaha berpengaruh positif dan signifikan terhadap kinerja bisnis. Orientasi Wirausaha terdiri dari indikator kemampuan berkreasi, proaktif, keberanian mengambil resiko, dan membangun jaringan. Kondisi ini memberikan sinyal kepada pelaku bisnis untuk dapat meningkatkan kinerja bisnis. Penelitian ini juga sejalan dengan yang dilakukan oleh Mustikowati dan Tysari (2014), bahwa orientasi kewirausahaan berpengaruh secara positif dan signifikan terhadap kinerja perusahaan yang memberi makna bahwa semakin baik orientasi kewirausahaan yang dimiliki seperti perilaku inovatif, perilaku proaktif dan pengambilan resiko, maka pencapaian kinerja perusahaan juga akan semakin baik. Dengan orientasi kewirausahaan yang semakin kuat maka akan membantu perusahaan dalam menciptakan ide baru, membuka peluang untuk melakukan penetrasi pasar dan melakukan percobaan meskipun beresiko, sehingga pada akhirnya dapat menjadi pemimpin pasar dengan melaksanakan strategi dan tujuan jangka panjang. Demikian halnya dengan yang dilakukan oleh Jayaningrum dan Sanawiri (2018), bahwa perusahaan yang melakukan orientasi kewirausahaan akan mampu berinovasi sehingga dapat menciptakan produk yang lebih unik atau menarik dibanding dengan pesaingnya. Penelitian ini juga sejalan dengan yang ditemukan oleh Suryanita (2006) bahwa ketika 
sebuah perusahaan memiliki derajat yang cukup tinggi menyangkut orientasi kewirausahaan maka hal ini akan mendukung terciptanya kinerja pemasaran secara langsung yang juga tinggi.

Dari hasil penelitian ini menunjukkan bahwa faktor kelembagaan tidak signifikan memoderasi pengaruh orientasi kewirausahaan terhadap kinerja usaha, artinya bahwa kinerja usaha ayam petelur tidak didorong oleh peran moderasi kelembagaan. Peran kelembagaan tidak mampu memperkuat pengaruh orientasi kewirausahaan terhadap kinerja usaha. Peran kelembagaa dalam melakukan pemberdayaan, permodalan, serta akses pasar tidak mampu mendukung para pengusaha ayam petelur. Penelitian ini berbeda dengan hasil penelitian yang dilakukan oleh Yeoh and Jeong (1995) tentang peran pemerintah (kelembagaan) dalam mempromosikan kewirausahaan di kalangan perusahaan pengekspor yang menjelaskan bahwa pemerintah sering bertindak sebagai penyangga perusahaan yang beroperasi di lingkungan yang tidak pasti. Penelitian ini juga tidak sejalan dengan yang dilakukan oleh Emine (2012) yang membuktikan bahwa ada hubungan positif yang signifikan antara dukungan keuangan Pemerintah dan pinjaman bank swasta untuk kinerja pertumbuhan UKM. Ketidakmampuan UKM sendiri untuk mengakses sumber daya teknologi dan manajerial yang memadai, bersama dengan upaya sederhana dari pemerintah, menunjukkan perlunya dukungan keuangan pemerintah. Meningkatkan infrastruktur keuangan harus menjadi item prioritas dalam agenda kebijakan. Lembaga pembiayaan pemerintah dan bank swasta melaporkan bahwa kekurangan dalam infrastruktur keuangan adalah salah satu kendala utama.

\section{KESIMPULAN}

Orientasi kewirausahaan mampu meningkatkan kinerja usaha peternakan ayam petelur di Kecamatan Baranti Kabupaten Sidrap, sedangkan peran kelembagaan tidak mampu memperkuat orientasi kewirausahaan agar meningkatkan kinerja usaha peternakan ayam petelur di Kecamatan Baranti Kabupaten Sidrap.

\section{DAFTAR PUSTAKA}

Badan Pusat Statistik kabupaten Sidrap, 2015

Dinas peternakan sulsel, 2012

Haliq Idham, 2017, Pengaruh Orientasi kewirausahaan terhadap kinerja usaha peternakan ayam broiler di kabupaten bogor, tesis, Institut Pertanian Bogor.

Hanuna Shafariah, Edison \& Rio Mattajang, 2016, Hubungan orientasi kewirausahaan dengan pertumbuhan UMKM: Peran aspek permodalan dan pemerintah sebagai moderator, Jurnal Riset Manajemen dan Bisnis Vol.1, No.1 : 61-70 ISSN $2527-7502$

Palmarudi Mappigau dan A. Sawe Ri Esso, 2011, Analisis strategi pemasaran telur pada peternakan ayam ras skala besar di kabupaten sidrap, Jurnal Agribisnis, Vol X (3) september.

Sitti Nurani Sirajuddin, Fahkrullah, Sri Hidayati, 2016, Seminar Nasional Peternakan 2, Fakultas Peternakan Universitas Hasanuddin Makassar, 25 Agustus 2016

St. Rohani, dan Irma susanti, 2012, Profil peternak ayam petelur berdasarkan skala usaha di kabupaten sedenreng rappang sulawesi selatan, Universitas sulawesi barat.

Sugiyono,2006. Statistik nonparametris untuk penelitian, Cetakan Kedua, Bandung: CV. Alfabeta

Suryanita Andriani, 2006, Analisis pengaruh orientasi kewirausahaan dan kompetensi pengetahuan terhadap kapabilitas untuk meningkatkan 
kinerja pemasaran, tesis program

studi magister manajemen, program pascasarjana, Universitas Diponegoro.

Yamin Sofyan, Heri Kurniawan, 2011, Partial Least Square Path Modeling, Salemba Empat. 